Society to promote "the Austrian federal state idea," as expressed in the first paragraph of the statutes of the society, the Austriaca-Studierzentrum is also referred to as the Bundesländer-Zentrum, since much of the material in it deals with the individual federal states and their past and present contributions to the common Austrian state.

Pro Austria Society

EdToRIAL STAFF

\title{
The Institute for Contemporary History of the University of Vienna
}

From the time of its establishment in June, 1966, the Institute for Contemporary History (Institut für Zeitgeschichte) of the University of Vienna has functioned as both a teaching and a research institute.

Originally the personnel of the institute consisted of only one professor, a single assistant, and one librarian. However, by 1968 there were 450 students attending the lecture course given in the institute and 45 students in the seminar. In addition, 40 students were working on dissertations. To aid in handling the increased work load, another assistant was allotted to the institute in that same year.

Of the 39 completed dissertations approved by the institute between 1966 and 1970,12 had either already been published in collective works or journals by the summer of 1970 or else were in the process of publication. Prizes have been awarded to the authors of 14 of these 39 dissertations.

The research materials of the institute have increased considerably during the past few years. The library, which originally contained 4,900 volumes put at its disposal by the Austrian Society for Contemporary History (Osterreichische Gesellschaft für Zeitgeschichte) in 1966, now has approximately 12,000 volumes. With the cooperation of the Austrian Society for Contemporary History, the institute has been able to make substantial additions to its collections of documents, memoirs, pictures, and recordings. Especially worthy of mention has been the institute's work in preserving the records of criminal court trials that are of historical importance. One thousand, five hundred of these records are now in microfilm form in the institute's archive.

The institute has cooperated in the production of programs 
based on materials in its archive and library for various Austrian, German, and Italian radio and television networks. Members of the institute are working on important publications, such as the Lexikon zur Politik und Geschichte des 20. Jahrhunderts, and are publishing articles in both Austrian and foreign journals. They have given a large number of lectures away from the university, especially in the federal provinces. Among the most important research projects planned by the institute for the near future are a study, in cooperation with Italian historians, of the relations between Italy and Austria in the twentieth century; a lexicon of the history of the Austrian Republic; a publication of sources on the Austrian resistance against the National Socialist regime; and a volume on the National Socialist putsch attempt of 1934 .

Recently the following volumes have been added to the institute's publication series: Gabriele Hindinger, Das Kriegsende und der Wiederaufbau demokratischer Verhältnisse in Oberösterreich im Jahre 1945; Karl Stuhlpfarrer, Die Operationszonen "Alpenvorland" und "Adriatisches Küstenland" 1939-45; and Norbert Schausberger, Geschichte der Rüstungsindustrie auf dem Gebiet der sogenannten Donau- und Alpenreichsgaue 1938-45. A volume by Karl Haas on Studien zur Wehrpolitik der österreichischen Sozialdemokratie 1918-26 is now being prepared for publication.

University of Vienna

LUDWIG JEDLICKA

Study Group on Central and East Central European Cultures

The Austrian Institute of Eastern and Southeastern European Studies (Osterreichisches Ost- und Südosteuropa-Institut), together with the Austrian UNESCO Commission, organized a conference which was held in Vienna on June 2223,1970 , to consider plans for the establishment of a Study Group on Central and East-Central European Cultures. Present at the meeting were delegates from several countries such as Poland, Hungary, Jugoslavia, Romania, Austria, the German Federal Republic, and the United States. Among the participants were the following UNESCO delegates: Guy S. Métraux, the director of the cultural division; Secretary General Sir Ronald Syme, who came as the representative of 